Jurnal Keperawatan Padjadjaran

ISSN 2338-5324 (print)

ISSN 2442-7276 (online)

Online di http://jkp.fkep.unpad.ac.id

DOI : $10.24198 / \mathrm{jkp}$

\title{
The Mental Burden of Parents of Children with Thalassemia
}

\author{
Gita Septyana, Ai Mardhiyah, Efri Widianti \\ Faculty of Nursing, Universitas Padjadjaran, Bandung, Indonesia \\ Corresponding Email: ai.mardhiyah@unpad.ac.id
}

Submitted: 13-03-2019 Accepted: 22-04-2019 Published: 28-04-2019

\begin{abstract}
Thalassemia is an inherited blood disorder in which there is a chronic abnormality of red blood cells. When a child suffers from a severe illness, the family usually acts as caregivers, which put them at risk of experiencing a burden of care. This study aims to identify the level of charge perceived by parents caregivers of children with thalassemia. A quantitative approach was used in this research to obtain data by using a continuous sampling. The samples in this research consisted of 71 parents of children with thalassemia, who are either their biological father or mother who attended thalassemia center on August 30, 2017 - September 13, 2017. The instrument was used in this research was modified from a Caregiver Burden Scale instrument (developed by Elmstahl). The data obtained were analyzed using a descriptive statistical technique in which parents burden is categorized into three levels: mild, moderate, and severe levels of burden, and they are measured in percentage. The result showed that 36 respondents $(50.7 \%)$ perceived a mild level of burden, 31 respondents $(43.7 \%)$ perceived moderate level of burden, and four respondents $(5.6 \%)$ saw the severe level of burden. This study concludes that most respondents perceived a mild and moderate level of burden, but in terms of responsibility, economy, expectation, and anxiety, they showed a severe degree of burden. Nurses are suggested to maintain or alleviate the burden by providing education, counseling, emotional support and adaptive coping mechanisms for parents of children with thalassemia.
\end{abstract}

Keywords: Burden, parents, thalassemia. 


\section{Introduction}

Thalassemia is one of hereditary and the most common cronic diseases. Thalassemia is a heterogeneous group of the hemoglobin disorders in which the production of normal hemoglobin is partly or completely suppressed as a result of the defective synthesis of one or more globin chains the most common types of clinical importance being $\alpha, \beta$, and $\delta$ thalassemia (Cappellini, Cohen, Eleftheriou, Piga, Porter, Taher, 2008)

Thalassemia incidence in Indonesia is relatively high, and the country is included in high-risk countries, 3,000 babies born to have thalassemia every year (Mulyani, 2011). Twenty percent of babies born in West Java carry the traits of thalassemia. Yayasan Thalassemia Indonesia-Perhimpunan Orangtua Penderita Thalassemia (YTIPOPTI) recorded 7,238 thalassemia major sufferers in 2016, and 3,200 (45\%) of them were residents of West Java. West Java is the area with the largest number of thalassemia patients in Indonesia (Widiyatno, 2016).

Clinical symptoms of $\beta$ thalassemia include anemia, jaundice, growth retardation, facial bone deformities, enlarged spleen, and susceptibility to infection (James, 2007). Besides, thalassemia might result in psychological and social disorders such as anxiety, depression and social withdrawal (Cakaloz, 2009). Children with symptoms of thalassemia, especially those who have experienced complications, require more excellent care and attention from their family.

Furthermore, the fact that thalassemia cannot be cured permanently requires children with thalassemia to perform regular blood transfusion to live. The transfusion is presented every two to four weeks (Mulyani, 2011). However, routine blood transfusion therapy will cause iron overload in the body, which in turn will require sailing therapy. This lifetime therapy requires constant care and attention from the family.

A person who provides care to a patient is called caregiver (Sukmarini, 2009). Family can provide caring support in different ways, such as emotional, physical, and financial support as well as coordinating with health care and social services, routine health care (getting medicines), personal care such as eating, bathing, and dressing, assisting homework and financial arrangements (Toesland, 2001).

Providing care and attention to children with thalassemia in the long term will impose a burden on the family. Caregiver burden is a multidimensional response with negative perception and stress resulting from caring for a sick individual (Zarit, 1980). According to Solve Elmstahl (1996), caregiver burden comprises five factors: general strain, isolation, disappointment, emotional involvement, and environment.

The burden might impact the caregivers both physically and psychologically. A research conducted by Sivansh Inamdar in 2008 revealed that $60 \%$ of parents of children with thalassemia are burdened and stressed due to the chronic nature of the disease. Furthermore, research by Pouraboli (2017) also mentioned that families whose children suffer from thalassemia in Iran felt psychological, financial, and isolation burdens, not to mention suffering from social stigma in the care situation.

Physical and psychological health of caregivers is negatively affected as a result of the burden imposed on them in the care situation. Parents of thalassemic children showed severe stress in parenting, and it was reported that $67.5 \%$ of parents experienced psychological distress (Ali, Sabih, Jehan, Anwar, \& Javed, S. 2012). Besides, psychosocial problems are also experienced by parents in caring for children with thalassemia. The difficulties encountered by parents of children with thalassemia, among others, are that they concern about the child's physical weakness (caused by anemia), about financial difficulties, and the child's future (Prasomsuk, Jetsrisuparp, Ratanasiri, \& Ratanasiri, 2007).

Influenced by either cultural and religious beliefs that view the course of life as predetermined and set in destiny, many people in Indonesia maintain the attitude of acceptance. (Koentjaraningrat, 2000). This attitude of acceptance is also reflected in coping with the fact that their children suffer from a chronic illness. Indonesian people, especially Sundanese ethnic group, has very close kinship ties (Sudiharto, 2007) and preserve a cooperation culture. When 
Gita Septyana: The Mental Burden of Parents of Children wth Thalasemia

a family member is down with the illness, the rest of the family will join together in caring for the ill by providing either physical, material, or emotional support. (Suprajitno, 2004). These traits are likely to have an impact on caregiver's burden in caring for children with thalassemia in Indonesia, which distinguishes them from caregiver burden in other countries.

According to our interview with the parent's thalassemic children, most of them revealed that they felt exhausted because they had to take their children for blood transfusion therapy every month. Some of them even had to skip work to be able to do that. They also felt exhausted because they were always so worried about the condition of their children that they did not have time to think about their own. Based on this phenomenon, this research focuses on the parents burden as caregivers of children with thalassemia.

\section{Method}

This research is quantitative and descriptive. This research was conducted at Sumedang Regional General Hospital (RSUD henceforth), West Java, Indonesia. The variable in this research is a single variable, which is a family burden as caregivers in thalassemic children with sub-variables of general strain, isolation, disappointment, emotional involvement, and environment. The population in this research is families who act as caregivers of thalassemic children at RSUD Sumedang. Using consecutive sampling technique with the criterion of biological mother or father from children six months old Thalassemia up to 12 years old who come to the hospital. On this research,
71 respondents participated in the period of 2 weeks (31 August-13 September 2017 2017).

The instrument used in this research was the Caregiver Burden Scale developed by Elmstahl in 1996. The tool comprises 22 questions covering 5 sub-variables of caregiver burden: general strain (8 questions), isolation (3 questions), disappointment (5 questions), emotional involvement (3 questions), and environment (3 questions). In doing so, a Likert scale of was used to determine the answers: "never", "seldom", "sometimes", and "often."

The instrument is a standard instrument with a validity value of 0.70 . The instrument was back-translated. This instrument is already done back translate by Jasmia (2016) where the translation is done by linguists of the language centre, Faculty Culture of Padjadjaran University that translates from English to English by Tisna Prabasmoro, Ph.D and translated back into English by Rasus Budhoyono, M.Hum.

It using face validity, validated by 10 people with the same characteristics as the samples. Words that are not understood by the respondents were simplified so it would be easier to understand and answer the questions. Data analysis was conducted using descriptive statistical analysis in which parents burden was categorized into 3 proportions: mild average score 1.00-1.99, moderate average score of 2.00-2.99, and severe levels score $3.00-4.00$. Further analysis of the burden of parents use in percentage.

\section{Result}

The table above shows that 48 respondents (67.6\%) age between 18-40 (early adult), 60 respondents are female $(84.5 \%)$ and

Table 1 Traits of Parent of Children with Thalassemia $(n=71)$

\begin{tabular}{llcc}
\hline & Category & f & \% \\
\hline Age & $\begin{array}{l}18-40 \text { years old (early } \\
\text { adult) } \\
\end{array}$ & 48 & 67.6 \\
& $>60$ year old (elderly) & & 31 \\
& Female & 22 & 1.4 \\
Gender & Male & 1 & 84.5 \\
& Mother $\quad 60$ & 11 & 15.5 \\
Family Relationship & $\quad$ Father & 60 & 84.5 \\
\hline
\end{tabular}


Gita Septyana: The Mental Burden of Parents of Children wth Thalasemia

\begin{tabular}{llcc} 
Education Level & Primary School & 23 & 32.4 \\
& Junior High School & 24 & 33.8 \\
& High School & 19 & 26.8 \\
& Vocational & 1 & 1.4 \\
& Bachelor's Degree & 4 & 5.6 \\
Employment Status & Employment & 16 & 22.5 \\
& Unemployment & 55 & 77.5 \\
Income & Under minimum wage & 49 & 69.0 \\
& Above minimum wage & 22 & 31.0 \\
Duration of Treatment & $1-11$ months & 3 & 4.2 \\
& $1-5$ years & 16 & 22.5 \\
6-12 years & 52 & 73.2 \\
Number of children with & 1 child & 61 & 85.9 \\
thalasemia & 2 children & & 12.7 \\
& $>2$ children & 9 & 1.4 \\
Other support & Family & 1 & 74.6 \\
BPJS/Other insurance & Professional support & 53 & 1.4 \\
beneficiaries & None & 1 & 23.9 \\
& No & 17 & 100 \\
\hline
\end{tabular}

Table 2 Parent Burden as Caregivers of Children with Thalassemia $(n=71)$

\begin{tabular}{lccc}
\hline & Burden & f & \% \\
\hline Mild & 36 & 50.7 \\
Moderate & 31 & 43.7 \\
Severe & 4 & 5.6 \\
\hline
\end{tabular}

Table 3 Burden Level in Terms of Sub-Variables of Parents of Children Thalassemia $(n=71)$

\begin{tabular}{lcc}
\hline \multicolumn{1}{c}{ Sub-variables } & f & \% \\
\hline General strain & & \\
Mild & 28 & 39.4 \\
Moderate & 33 & 46.5 \\
Severe & 10 & 14.1 \\
Isolation & & \\
Mild & 54 & 76.1 \\
Moderate & 16 & 22.5 \\
Severe & 1 & 1.4 \\
Disappointment & & \\
Mild & 19 & 26.8 \\
Moderate & 34 & 47.9 \\
Severe & 18 & 25.4 \\
Emotional involvement & & \\
\hline
\end{tabular}


Gita Septyana: The Mental Burden of Parents of Children wth Thalasemia

\begin{tabular}{lcc}
\hline Mild & 51 & 71.8 \\
Moderate & 13 & 18.3 \\
Severe & 7 & 9.9 \\
Environment & & \\
Mild & 17 & 23.9 \\
Moderate & 45 & 63.4 \\
Severe & 9 & 12.7 \\
\hline
\end{tabular}

60 respondents $(84.5 \%)$ are mothers of thalassemic children. 24 respondents $(33.8 \%)$ are junior high school graduates, 55 respondents $(77.5 \%)$ are unemployed, 49 respondents $(69 \%)$ have income below minimum wage. $73.2 \%$ respondents have cared for their thalassemic children for 6-12 years. 61 respondents $(85.9 \%)$ have 1 thalassemic child, 53 respondents $(74.6 \%)$ have other family members helped caring for their thalassemic children, and 71 respondents (100\%) are BPJS/other insurance beneficiaries.

The table above shows that 36 respondents (50.7\%) participated in this research perceived mild level of burden. 31 respondents $(43.7 \%)$ perceived moderate level of burden, while only 4 respondents ( $5.6 \%)$ who perceived severe level of burden.

The table above shows that, in subvariable of general strain, 33 respondents $(46.5 \%)$ perceived moderate level of burden as caregivers. In sub-variable of isolation, 54 respondents $(76.1 \%)$ perceive mild level of burden. In sub-variable of disappointment, 34 respondents $(47.9 \%)$ perceive moderate level of burden. In sub-variable of emotional involvement, 51 respondents $(71.8 \%)$ perceive mild level of burden. In sub-variable of environment, 45 respondents $(63.4 \%)$ perceive moderate level of burden.

\section{Discussion}

Based on the result, it was found that the level of caregiver burden among parents of children with thalassemia are generally mild $(50.7 \%)$, while $43.7 \%$ of the respondents perceived moderate level of burden, and only $5.6 \%$ of the respondents that perceived severe level of burden. The burden of the elderly as a caregiver is the mental pressures or loads that appear on the parents who care for individuals with chronic disease. Caregiver tends to lack of rest, less intake of food, and when the pain usually does not come to health services, it would have an effect on daily activities and care given to the children of thalassemia. (Barbara, 2015).

The burden of the elderly at mild levels indicate parents are having a little trouble on a general strain for responsible care, a little experience feelings of isolation or feeling disappointed, and a little experience difficulties in the environment. The perceived lightness of burden likely will not interfere with the activities of daily caregiver.

Parents believe that the child is a mandate from God that must be preserved. Although the child's condition however and though treatment costs a pricey parents will strive to take care of children (Ambarsari, 2012).

Based on the sub-variable of the general strain, the question item with the highest level of burden is concerning responsibility for the welfare of the child. This is possibly because, according to Friedman (2010), one of the primary functions of family is to provide the essentials to keep the family healthy. The health care function of this family member is a function to carry out health care practice, which is to prevent disease and to care for sick family members. Therefore, families tend to feel responsible in caring for sick their members and responsible for their wellbeing.

The fact that most of the respondents were mothers of children with thalassemia is most likely the contributing factor to the high level of burden. In Indonesia, many people believe that it is almost exclusively a mother's role to take care of children (Hanifah, Mediani \& Nurhidayah, 2018). This is in accordance with Begum (2016) in Jasmia (2017) who stated that women are assigned with domestic 
responsibilities, including taking care of family members. Therefore, the burden perceived by female caregivers is higher than their male counterparts. In the current study parents, mostly mothers (84.5\%) takes his son for medical treatment undergoes mental burden is light $(50.7 \%)$.

The next question item with the second highest level of burden is concerning insoluble problems during treatment. One of the tough problems that caregivers encounter during blood transfusion therapy is a shortage of blood supply from the Indonesia Red Cross Society. This condition forces them to be able to find blood donors for their children. This problem is in accordance with the research conducted by Prasomsuk, Jetsrisuparp, Ratanasiri, \& Ratanasiri, (2007) which revealed that one of the problems experienced by parents of children with thalassemia is getting further treatment for their children, such as splenectomy and blood transfusion therapy.

In the sub-variable of isolation, most of the caregiver perceived mild level of burden $(76.1 \%)$. Most of the respondents did not experience deteriorating relationships with friends and relatives. Family and friends play an important role in sharing information and experiences about home care and treatment (Prasomsuk, Jetsrisuparp, Ratanasiri, \& Ratanasiri, 2007). A good relationship with friends contribute positively to caregiver burden, especially in terms of isolation. Sudiharto (2007) said that the people of Indonesia especially the Sundanese people have very close kinship ties, when there are family members who are sick then the rest of the family will alleviate the burden of isolation.

Burden on caregiver on sub-variables disappointment, a small portion of respondents experienced high disappointment (25.4\%). Parents of children with Thalassemia wish all their family members to be in good health and without any abnormalities. The family realizes that thalassemia is an incurable disease, but they expect their child's health to improve so that they can live with them as long as possible, get an education as high as possible and have a good future (Prasomsuk, Jetsrisuparp, Ratanasiri, \& Ratanasiri, 2007). High expectations led to disappointment and burden on caregivers. Besides that, parents thalassemic children were disappointed with the present health services, the amount of information provided to them, the means of transport and their financial conditions (Pruthi \& Singh, 2010).

It was also revealed that most of the respondents complained about the high cost of taking their children to the hospital. Moreover, $69 \%$ of the respondents participated in this research have monthly income below minimum wage. The high cost of thalassemia treatment financially burdens them as caregivers.

In the sub-variable of emotional involvement, $71.8 \%$ of the caregivers perceived mild level of burden. Emotional involvement perceived negative feelings parents caregiver when interacting with children suffering from Thalassemia. Research by Ambarsari (2012) mentions that in taking care of sick children, more patient and caregiver rests in God. The existence of a patient and a feeling of confidence to God that all that happened as a test and need patiently provide strength in dealing with issues related to child condition.

In this sub-variable, the question item with the highest level of burden perceived by caregivers is about being offended by and upset about their thalassemic children. According to Darwis (2006), everybody feels emotion. Caregivers of children with thalassemia are also human beings with emotion. When being confronted with their thalassemic children who (like any other children) sometimes could be disobedient, they might be upset and angry at them.

In the sub-variable of environment, $63.4 \%$ of the respondents perceived moderate level of burden. In the sub-variable of environment, the burden is caused by "anxiety of not being able to properly take care their children." Anxiety is unrealistic fear (Gunarsa, 2008). Anxiety is a subjective feeling of disturbing mental tension as a general reaction to the inability to cope with a problem or lack of security (Rochman, 2010). Thoughts about the future, stressful situations, fear of losing or fear of being left alone with great responsibility of caring for other family members experienced by the family are the cause of high anxiety (Duci, 2012). 
Some of the effects of anxiety are sleep deprivation that might lead to irritability, inability to pay attention to the real problems, which in turn, will prevent an individual from functioning effectively (Cohen, 2002). Caregivers with excessive anxiety will undertake ineffective care that will result in a deterioration in the patient's condition.

Thalassaemia has an impact on children and families. Thus the family needs further information about thalassaemia and its treatment, emosional support, social support, professional suport and financial support (Mediani, Nurhidayah, Mardhiyah, \& Panigoro, 2017).

\section{Conclusion}

It can be concluded that most respondents participated in this research showed mild and moderate level of burden in caring for children with thalassemia This means that parents can still overcome feelings or pressures felt both feelings of responsibility, feelings of disappointment, isolation, emotional and feelings of the influence of the environment of children with thalassemia, so it does not interfere with the activities and care of their children. Only few respondents perceived severe level of burden. This is probably influenced by Indonesian cultural background of the caregivers that views the course of life as predetermined and set in destiny, which help them in coping with the situation.

In addition, the kinship of the people of Indonesia, especially Sundanese ethnic group, is very close. They value the tradition of mutual cooperation in which the entire family help each other in taking care of a sick family member, either in the form of physical, material, or psychological support to lighten the burden. Based on the question items in the sub-variables of burden, there are some aspects that highly perceived by the caregivers participated in this research, such as question items related to great responsibility for the thalassemic children welfare, about the hope for a different life , financial cost, and about anxiety.

It is necessary for nurses to relieve caregivers burden through education, counseling, social support, improving the ability of coping mechanisms so that it will not affect the physical and psychological health of caregivers.

Based on the results of this study is expected clinical nurses and the community can provide nursing care to families of children thalassemia both to educate about the disease and knowledge about the treatment. Clinical nurses should make time for counseling with caregivers when they take their children for blood transfusion therapy. By doing so, the real problems can be identified and nurses will be able to design family care nursing plan that suit both the needs of the patient and the caregivers.

\section{References}

Ali, S. S. (2012). Psychological Distress and Coping Strategies Among Parents of Beta Thalassemia Major Patients. International Conference on Clean And Green Energy, 124-128.

Aritonang, M. V. (2008). Pengalaman Keluarga dengan Anak yang Menderita Penyakit Kronis. (Family Experience with Children Suffering from Chronic Illness). Jurnal Keperawatan.

Barbara, S.-J. (2015). African American Wives and Perceived Stressful Experiences: Providing CAre for Stroke Survivor Spouses. ABNF Journal.

Begum, S. (2016). Level of Caregiver Burden : A Study of Caregivers of Stroke Survivors at CRP in Bangladesh. International Journal fo Medical Health Science.

Cakaloz, B. (2009). Psychopathology in Thalassemia Major. Pediatric International .

Cappellini MD, Cohen A, Eleftheriou A, Piga A, Porter J, Taher A. (2008) Guidelines for the clinical management of thalassaemia. 2nd ed. Cyprus: Thalassaemia International Federation.

Cohen, A. B. (2002). The importance of spirituality in well-being for Jews and 
Gita Septyana: The Mental Burden of Parents of Children wth Thalasemia

Christians. Journal of Happiness Studies, 3(3), 287-310.

Darwis, M. H. (2006). Emosi-Penjelajahan Religio Psikologis Tentang Manusia dalam Al-Quran. (Emotions-Religious Psychological Exploration of Humans in the Koran). Jakarta: Erlangga.

Duci, V. (2012). perceived Social Support and Coping Styles as Moderators of Levels of Anxiety, Depression, and Quality of Life in Cancer Caregivers: A Literature Review. European Scientific Journal, 160-173.

Elmstahl, S. (1996). Caregiver Burden of Patient 3 Years After Strole Assessed by A Novel Caregiver Burden Scale. International Journal, 160-173.

Friedman. (2010). Keperawatan Keluarga : Teori dan Praktik. (Family Nursing: Theory and Practice). Jakarta: EGC.

Gunarsa, S. (2008). Psikologi Perkembangan . (Developmental psychology). Jakarta: PT BPK Gunung Mulia.

Hanifah, A. R., Mediani, H. S., \& Nurhidayah, I. (2018, April). Pengalaman ibu merawat anak dengan talasemia mayor usia sekolah (6-12 tahun) di RSUP Dr. Hasan Sadikin Bandung. In Seminar Nasional Keperawatan , 1(1).

Mediani, H.S., Nurhidayah, I., Mardhiyah, A., Panigoro, R. (2017). Indonesian Mothers' and Concerns about having a Thalassemic Child and its Treatment: An Exploratory Qualitative Study. International Journal of Nursing Care; 1(2): 1-7.

Hockenberry, M.J. \& Wilson, D. (2013). Wong's essentials of pediatric nursing. Ninth Edition. Elseiver

Indriati. (2011). Pengalaman Ibu dalam Merawat Anak dengan Thalasemia di Jakarta. (Mother's Experience in Caring for Children with Thalassemia in Jakarta). Jurnal Keperawatan UI.

James, S. R. (2007). Nursing Care of Children $\therefore$ Principles and Practice. Saunders Elsevier.

Jeffrey. (2005). Psychology Abnormal. Jakarta: Erlangga.

Koentjaraningrat. (2000). Pengantar Ilmu Antropologi. (Introduction to Anthropology). Jakarta: Radar Jaya Offset.

Mulyani. (2011). Reaksi psikososial terhadap penyakit di kalangan anak penderita thalasemia mayor di Kota Bandung. Informasi, 16.

Mulyani. (2011). Reaksi Psikososial Terhadap Penyakit di Kalanagan Anak Penderita Thalasemia Mayor di Kota Bandung. (Psychosocial Reactions to Diseases among Children with Thalassemia Major in the City of Bandung). Informasi vol. 16.

Pouraboli, B., Abedi, H. A., Abbaszadeh, A., \& Kazemi, M. (2017). Self-care in patient with major thalassemia: A Grounded Theory. Journal of Caring Sciences, 6(2), 127.

Prasomsuk. (2007). Lived Experiences of Mothers Caring for Children With Thalassemia Major in Thailand. JSPN.

Pruthi, G. K. and Singh, T. B. (2010) Psychosocial burden and quatlity of life in parents of children with thalassemia and CP. Delhi Psychologist Journal, 2(1), 46-57.

Rochman, K. L. (2010). Depresi Tinjauan Psikologis. (Depression Psychological Review). Purwokerto: Fajar Media Press.

Solaeman. (2001). Ilmu Sosial Dasar. (Basic social knowledge). Bandung: PT Refika Aditama.

Sudiharto. (2007). asuhan keperawatan keluarga dengan pendekatan keperawatan transkultural. (family nursing care with a transcultural nursing approach). jakarta: EGC.

Sukmarini. (2009). Optimalisasi Peran Caregiver Dalam Penatalaksanaan Skizofrenia. (Optimizing the Role of the Caregiver in the Management of 
Gita Septyana: The Mental Burden of Parents of Children wth Thalasemia

Schizophrenia). Majalah Psikiatri, 58-61.

Widiyatno. (2016). Jumlah Penderita Thalasemia Terus Meningkat. (The Number of Thalassemia Sufferers Continues to
Increase). Jakarta: Republika.

Zarit, S. (1980). Relatives of The Impaired Elderly: Correlates of Feelings of Burden . The Gerontologist, 649-655. 